\title{
EKSISTENSI AAUPB DI INDONESIA DAN YURISPRUDENSINYA DALAM PERKARA TUN
}

\author{
Ikhsan Fatah Yasin \\ UIN Sunan Ampel Surabaya | Jl. A. Yani I 17 Surabaya \\ Ikhsan.fatahyasin@gmail.com
}

\begin{abstract}
This article discusses the General Principles of Good Governance (AAUPB). It has a long journey from the beginning of its coming in the Netherland to its application in Indonesia today. AAUPB, which previously was only in theoretical realm, it changes into Law No. 30 of 2014 today. The principles contained in the law are legal certainty; expediency; impartiality; accuracy; not to abuse authority; openness; public interest; and good service. In addition to these principles, we can also use other principles as far as they become the basis for the judges' judgments that have permanent legal force. In various cases, the basis of the claim of AAUPB does not stand alone but it is also juxtaposed with violations of statutory regulations. The Supreme Court verdict has become a jurisprudence between Suhaili Saun (shareholder in PT Volex Batamindah) and the Chairman of BKPM, although the plaintiff also argued that violating the AAUPB namely the principle of legal certainty, the defendant also violated article 2 letter b of Law No. I of 1967 about Foreign Investment. In the case of the dismissal of Bripda Helga Musa Sitepu by the Head of the North Sumatra Regional Police, the decree has violated article 2 paragraph 2 letter $d$ and article II paragraph I of KAPOLRI regulation No. 8 of 2006 and was contrary to the principle of the district.
\end{abstract}

Keywords: AAUPB, Jurisprudence, State Administration

Abstrak: Artikel ini membahas tentang Asas-Asas Umum Pemerintahan yang Baik (AAUPB), AAUPB memiliki perjalanan yang panjang dari awal kelahirannya di Belanda sampai penerapanya di Indonesia dewasa ini. AAUPB pada awal mulanya hanya berada dalam ranah teoritis baru kemudian masuk dalam undang-undang hingga AAUPB mendapatkan posisi yang sangat penting dalam UU No. 30 Tahun 2014, asas yang terdapat dalam undang-undang tersebut meliputi asas kepastian hukum; kemanfaatan; ketidakberpihakan; kecermatan; tidak menyalahgunakan kewenangan; keterbukaan; kepentingan umum; dan pelayanan yang baik. Selain asas-asas tersebut, bisa juga menggunakan asas lain selama

AL-DAULAH: JURNAL HUKUM DAN PERUNDANGAN ISLAM VOLUME 8, NOMOR 2, OKTOBER 2018 p-ISSN 2089-0109; e-ISSN 2503-0922

Homepage: http://jurnalfsh.uinsby.ac.id/index.php/aldaulah Email: judulsj@gmail.com 
dijadikan dasar penilaian hakim dalam putusan yang sudah mempuyai kekuatan hukum tetap. Dalam berbagai kasus, dasar gugatan karena AAUPB tidak berdiri sendiri tapi juga disandingkan dengan pelanggaran peraturan perundang undangan. Dalam putusan kasasi MA yang telah menjadi yurisprudensi antara Suhaili Saun (pemegang saham di PT Volex Batam Indah) dengan Ketua BKPM, meskipun penggugat mendalilkan juga bahwa selain melanggar AAUPB yaitu asas kepastian hukum, tergugat juga melanggar pasal 2 huruf b $\cup \cup$ No. I Tahun 1967 tentang Penanaman Modal Asing. Dalam kasus pemberhentian Bripda Helga Musa Sitepu oleh Kepala Kepolisian Daerah Sumatera Utara, surat keputusan tersebut melanggar pasal 2 ayat 2 huruf $d$ dan pasal I I ayat I peraturan KAPOLRI No. 8 Tahun 2006 dan bertentangan dengan asas kceramatan.

Kata kunci: AAUPB, Yurisprudensi, Administrasi Negara

\section{Pendahuluan}

Berkembangnya konsep welfare state mengharuskan pemerintah lebih aktif dalam menyejahterakan warga negaranya. Sebagaimana Negara-negara lain, Indonesia juga menganut welfare state. Konsep ini dapat kita temukan dalam UUD 1945 baik sebelum maupun sesudah amandemen. Dalam UUD 1945. Keaktifan pemerintah bukanya tanpa batasan, karena negara hukum mengharuskan kekuasaan pemerintah dibatasi dengan hukum yang disepakati oleh rakyat dalam bentuk konstitusi. Dari konstitusi inilah kemudian lahir berbagai produk hukum yang tak terhitung banyaknya, dari mulai undang-undang sampai peraturan daerah. Produk-produk hukum tersebut pada dasarnya ditujukan bagi kemakmuran dan kesejahteraan rakyat, meskipun secara das sein tidak semua peraturan tersebut bersifat demikian.

Karena kehidupan yang sangat dinamis dan sifat peraturan statis, maka pemerintah harus senantiasa berkreasi demi mewujudkan kesejahteraan bagi rakyat. Kreasi dari pemerintah yang demikian dikenal dengan freis ermessen atau diskresi. Diskresi adakalanya karena peraturannya memberikan pilihan, peraturannya tidak jelas, peraturannya tidak ada dan adakalanya 
juga karena kepentingan yang bersifat mendesak dan memerlukan penanganan segera.

Barometer untuk mengukur diskresi adalah AAUPB, diskresi dianggap berhasil jika sesuai dengan AAUPB begitu juga sebaliknya. Penerapan AAUPB di Indonesia memiliki perjalanan yang cukup panjang. Pada awal mulanya AAUPB hanya dikenal dalam dunia teoritis dan tidak diatur dalam peraturan perundangundangan, hanya saja Indonesia memang mengakui adanya hukum tidak tertulis yang bisa dijadikan landasan dalam memutuskan suatu perkara. Undang-Undang No. 9 Tahun 2004 adalah yang pertama kali mengenalkan AAUPB yang mana pada saat itu acuannya adalah Asas-Asas Penyelenggaraan Negara. Pengaturan lebih lanjut tentang AAUPB diperjelas dalam UU No. 30 Tahun 2014, dalam undang-undang tersebut AAUPB berada pada posisi yang sangat strategis.

Dalam tulisan ini, penulis ingin menjawab dua rumusan masalah: Pertama, bagaimana eksistensi Asas-Asas Umum Pemerintahan Yang Baik dalam penyelenggaraan pemerintahan di Indonesia?. Kedua, Bagaimana yurisprudensi dalam perkara TUN yang menyatakan sebuah beschikking bertentangan dengan AsasAsas Umum Pemerintahan Yang Baik

\section{Kelahiran Asas-Asas Umum Pemerintahan Yang Baik}

Asas-Asas Umum Pemerintahan Yang Baik dalam bahasa Belanda dinamakan sebagai algemene begiselen van behorlijk bestuur. Asas-Asas Umum Pemerintahan Yang Baik ini mengandung dua unsur penting, yakni pertama asas tersebut mengandung asas-asas yang sifatnya etis normatif dan kedua asas tersebut mengandung asas-asas yang sifatnya menjelaskan. Bersifat etis normatif maksudnya Asas-Asas Umum Pemerintahan Yang Baik dapat digunakan sebagai petunjuk melengkapi sesuatu sifat penting yang mengandung berbagai pengertian hukum, seperti asas persamaan, asas kepastian hukum dan asas kepercayaan. Makna dari sifat normatif ini yakni bahwa Asas-Asas Umum Pemerintahan Yang Baik mengatur kadar etis di dalam hukum administrasi 
penyelenggaraan pemerintahan. Sedangkan makna dari sifatnya yang menjelaskan adalah Asas-Asas Umum Pemerintahan Yang Baik tersebut memiliki sifat menjelaskan terhadap sejumlah peraturan hukum ${ }^{1}$. Sebagai asas hukum, Asas-Asas Umum Pemerintahan Yang Baik adalah asas hukum yang bahannya diturunkan dari susila (bahan hukum idiil) yang didasarkan pada moral. Moral berkaitan dengan etika, kesopanan, kepatutan, yang berdasarkan pada norma yang berlaku dalam kehidupan masyarakat yang baik dan sangat dipengaruhi oleh manusia. Karena Asas-Asas Umum Pemerintahan Yang Baik merupakan susila yang diturunkan dari moral, etika, kesopanan dan kepatutan yang berdasarkan pada norma yang berlaku dalam kehidupan masyarakat, maka Asas-Asas Umum Pemerintahan Yang Baik sebagai asas hukum juga mempunyai kekuatan mengikat dan harus dipatuhi oleh pejabat administrasi sebagaimana halnya dengan norma atau aturan hukum².

Asas-Asas Umum Pemerintahan Yang Baik yang biasa digunakan di Indonesia merupakan produk pemikiran dari Belanda, awal mula kelahiran asas-asas ini karena ketakutan akan terjadinya diskresi yang berlebihan dari pemerintah yang berakibat pada pelanggaran HAM. Oleh karena itu, pada tahun 1946 pemerintah Belanda membentuk komisi yang dipimpin oleh de Monchy yang diberikan tugas untuk memikirkan dan meneliti beberapa alternatif tentang Verhoogde Rechtsbescherming (peningkatan perlindungan hukum bagi rakyat dari tindakan administrasi Negara yang menyimpang), pada tahun 1950 komisi tersebut melaporkan hasil penelitiannya tentang Verhoogde Rechtsbescherming dalam bentuk algemene beginselen van behoorlijk bestuur (asas-asas umum pemerintahan yang baik). Namun hasil penelitian komisi ini tidak seluruhnya disetujui oleh pemerintah

\footnotetext{
SF. Marbun, Eksistensi Asas-Asas Umum Penyelenggaraan Pemerintahan Yang Layak Dalam Menjelmakan Pemerintahan Yang Baik dan Bersih Di Indonesia, Disertasi, tidak diterbitkan, program pasca sarjana fakultas hukum Universitas Padjajaran Bandung, 200 I), 50

2 Ibid. 69.
} 
dan pada akhirnya komisi ini dibubarkan, diganti dengan komisi Greenten. Komisi greenten yang bertugas sama dengan komisi de monchy ternyata juga mengalami nasib yang sama karena ada beberapa hal yang tidak disetujui oleh pemerintah. Meskipun kedua komisi ini dibubarkan oleh pemerintah, namun hasil penelitian mereka (khususnya dari komisi de Monchy) dipergunakan dalam pertimbangan putusan-putusan Raad van State dalam perkara administrasi ${ }^{3}$.

Dalam yurisprudensi awal mula diperkenalkannya Asas-Asas Umum Pemerintahan Yang Baik yakni sejak berlakunya Amtenarenwet 1929 pada tanggal 1 Maret 1933. Central Raad van Boroep dalam putusannya tanggal 22 Juni 1933 mengenai urusan pegawai negeri menyatakan ia tidak akan membatasi diri pada gugatan yang diajukan atas dasar hukum tertulis dan karenanya pemerintah seharusnya terikat kepada asas-asas hukum umum. Sedangkan yurisprudensi yang dibuat oleh hakim sipil memperkenalkan Asas-Asas Umum Pemerintahan Yang Baik semenjak adanya putusan Hoge Raad yang dalam putusan tersebut menunjukkan dengan jelas adanya pelanggaran terhadap norma hukum tidak tertulis dalam melaksanakan atau menggunakan wewenang hukum publik, sehingga tindakan atau wewenang hukum publik dianggap tidak sesuai dengan pengertian hukum dalam pasal 1401 BW. Dalam peraturan perundang-undangan, Asas-Asas Umum Pemerintahan Yang Baik diterima karena refleksi dari yurisprudensi dan ilmu pengetahuan hukum administrasi, sehingga Asas-Asas Umum Pemerintahan Yang Baik diterima dalam peraturan perundang-undangan cukup lama jika dibandingkan dalam yurisprudensi ${ }^{4}$.

\section{Asas-Asas Umum Pemerintahan Yang Baik di Indonesia}

\footnotetext{
${ }^{3}$ Ridwan HR, Hukum Administrasi Negara, Edisi Revisi, Cetakan Kedelapan, (Jakata: Raja Grafindo Persada, 20I3), 23I-232.

${ }^{4}$ SF. Marbun, Eksistensi...., I49-I50.
} 
Sebelum melangkah lebih jauh dalam pembahasan eksistensinya, terlebih dahulu akan saya paparkan mengenai AsasAsas Umum Pemerintahan Yang Baik yang berkembang di Indonesia. Crincen de Roy merangkum sebelas butir Asas-Asas Umum Pemerintahan Yang Baik yang berasal dari algemene van behorlijk bestuur yang diterima di lingkungan hukum administrasi Belanda, kesebelas asas tersebut yaitu:

1. Asas kepastian hukum

2. Asas keseimbangan

3. Asas kesamaan dalam mengambil keputusan

4. Asas bertindak cermat

5. Asas motivasi untuk setiap putusan

6. Asas tidak mencampuradukkan kewenangan

7. Asas permainan yang layak

8. Asas keadilan dan kewajaran

9. Asas menanggapi penghargaan yang wajar

10. Asas meniadakan akibat keputusan yang batal

11. Asas perlindungan atas pandangan (cara) hidup pribadi

Asas-asas tersebut kemudian dikembangkan dan disebarluaskan oleh Kuntjoro Purbopronoto dengan menambahkan dua asas, yaitu asas kebijaksanaan dan asas penyelenggaraan kepentingan umum.

Eksistensi Asas-Asas Umum Pemerintahan Yang Baik di Indonesia, secara tidak langsung diakui dan dijamin dalam penjelasan UUD 1045 sebelum amandemen, dimana bunyi penjelasannya sebagai berikut 5 :

“Undang-Undang Dasar suatu Negara ialah hanya sebagian dari hukumnya dasar Negara itu. Undang-Undang Dasar ialah hukum dasar yang tertulis, sedang disampingnya hukum dasar itu berlaku juga hukum dasar yang tidak tertulis, ialah aturan-aturan dasar yang timbul dan terpelihara dalam praktek penyelenggaraan Negara, meskipun tidak tertulis."

${ }^{5}$ Penjelasan UUD 1945 
Selain dalam penjelasan UUD 1945 sebelum amandemen, jaminan hukum tidak tertulis juga ditemukan dalam berbagai peraturan perundang-undangan yang lain, seperti dalam pasal 14 ayat 1 UU No. 14 Tahun 1970 tentang ketentuan-ketentuan pokok kekuasaan kehakiman yang diubah dengan undang-undang nomor 35 Tahun 1999, bunyi dari salah satu pasal tersebut adalah: ${ }^{6}$

"Hakim sebagai organ pengadilan dianggap memahami hukum. pencari keadilan datang kepadanya untuk memohon keadilan. Andaikata ia tidak menemukan hukum tertulis, ia wajib menggali hukum tidak tertulis untuk memutuskan berdasarkan sebagai seorang yang bijaksana dan bertanggung jawab penuh kepada Tuhan Yang Maha Esa, diri sendiri, masyarakat, Bangsa dan Negara."

Hal senada juga ditemukan dalam beberapa ketetapan MPR, antara lain TAP MPR No. II/MPR/1993 jo TAP MPR No. II/MPR/1998 tentang Garis Besar Haluan Negara, khususnya mengenai materi hukum, isi dari TAP MPR tersebut menyatakan bahwa meteri hukum meliputi aturan hukum tertulis dan tidak tertulis, berlaku dan mengikat semua penduduk dalam kehidupan bermasyarakat, berbangsa dan bernegara. Dengan demikian, dapat ditegaskan bahwa penyelenggaraan Negara RI bertumpu pada dua pilar hukum dasar, yakni hukum dasar tertulis dan hukum dasar tidak tertulis?

Fungsi Asas-Asas Umum Pemerintahan Yang Baik sebagai patokan, pegangan, arahan dan dasar bagi hakim peradilan administrasi dalam menilai atau membatalkan sebuah keputusan yang dikeluarkan oleh badan/pejabat administrasi Indonesia dalam JUKLAK MA No 052/Td.TUN/III/1992 tanggal 24 Maret 1992 hanya dimungkinkan dimasukkan dalam "pertimbangan hukum" suatu putusan, dengan menyebutkan asas mana dari AAUPB tersebut yang dilanggar dan tidak boleh dimasukkan dalam "diktum putusan" 8 .

\footnotetext{
${ }^{6}$ UU No 14 Tahun 1970 tentang Ketentuan-Ketentuan Pokok Kekuasaan Kehakiman.

7 Ibid., 73-74.

${ }^{8}$ Ibid., 134 .
} 
Pengaturan mengenai hukum administrasi di Indonesia mengacu kepada UU No. 5 Tahun 1986 yang telah mengalami beberapa kali revisi. Revisi undang-undang tersebut banyak membawa perubahan yang cukup penting dalam hukum acara PTUN, salah satunya berkaitan dengan alasan gugatan dengan dimasukannya Asas-Asas Umum Pemerintahan Yang Baik sebagai salah satu alasan yang dapat digunakan untuk menggugat keputusan tata usaha Negara sebagaimana yang terdapat dalam pasal 53 ayat 2 (b). Sebelum perubahan pasal tersebut berbunyi sebagai berikut ${ }^{9}$ :

\section{Pasal 53}

1) Seseorang atau badan hukum perdata yang merasa kepentingannya dirugikan oleh suatu keputusan tata usaha Negara dapat mengajukan gugatan tertulis kepada pengadilan yang berwenang berisi tuntutan agar keputusan tata usaha negara yang disengketakan itu dinyatakan batal atau tidak sah, dengan atau tanpa disertai tuntutan ganti rugi dan/atau rehabilitasi

2) Alasan-alasan yang dapat digunakan dalam gugatan sebagaimana dimaksud dalam ayat 1 adalah:

a. Keputusan Tata Usaha Negara yang digugat itu bertentangan dengan peraturan perundang-undangan yang berlaku

b. Badan atau pejabat Tata Usaha Negara pada waktu mengeluarkan keputusan sebagaimana dimaksud dalam ayat 1 telah menggunakan wewenangnya untuk tujuan lain dari maksud diberikannya wewenang tersebut

c. Badan atau pejabat Tata Usaha Negara pada waktu mengeluarkan keputusan atau tidak mengeluarkan keputusan sebagaimana dimaksud dalam ayat 1 setelah mempertimbangkan semua kepentingan yang 
tersangkut dengan keputusan itu seharusnya tidak sampai pada pengambilan atau tidak pengambilan keputusan tersebut.

Bunyi revisi dari pasal tersebut sebagai berikut ${ }^{10}$ :

Pasal 53

1) Orang atau badan hukum perdata yang merasa kepentingannya dirugikan oleh suatu keputusan tata usaha Negara dapat mengajukan gugatan tertulis kepada pengadilan yang berwenang berisi tuntutan agar keputusan tata usaha negara yang disengketakan itu dinyatakan batal atau tidak sah, dengan atau tanpa disertai tuntutan ganti rugi dan/atau rehabilitasi

2) Alasan-alasan yang dapat digunakan dalam gugatan sebagaimana dimaksud dalam ayat 1 adalah:

a. Keputusan Tata Usaha Negara yang digugat itu bertentangan dengan peraturan perundang-undangan yang berlaku

b. Keputusan Tata Usaha Negara yang digugat itu bertentangan dengan asas-asas umum pemerintahan yang baik

Meskipun dalam pasal 53 UU No. 5 Tahun 1986 tidak disebutkan secara eksplisit tentang Asas-Asas Umum Pemerintahan Yang Baik, namun dalam prakteknya pasal 53 ayat 2 huruf c pada kata "semua kepentingan yang tersangkut dengan keputusan itu" ditafsirkan sebagai asas-asas umum pemerintahan yang baik Dalam disertasinya, SF. Marbun juga mengatakan ${ }^{11}$

\footnotetext{
10 UU No 9 Tahun 2004 tentang perubahan atas undang-undang no 5 Tahun 1986 tentang peradilan Tata Usaha Negara

" SF. Marbun, Eksistensi..., I83. Selanjutnya ia mengatakan meskipun dalam pasal 53 UU No 5 Tahun 1986 sebelum direvisi tidak terdapat penamaan AAUPB, namun dalam penyelenggaraan pemerintahan yang dimaksud hukum tidak tertulis dalam penjelasan ayat tersebut adalah AAUPB sehingga secara fungsional AAUPB sudah bisa digunakan oleh hakim peradilan administrasi untuk menguji suatu keputusan yang dikeluarkan atas dasar kewenangan bebas.
} 
Kedua asas yang dicantumkan dalam UU No. 5 Tahun 1986 tersebut adalah:

a. Suatu keputusan yang dikeluarkan atas dasar penyalahgunaan kekuasaan (de tournament de pouvoir)

b. Suatu keputusan yang dikeluarkan atas dasar perbuatan sewenang-wenang (a bus de droit willikeur)

Meskipun demikian, berkaitan dengan pasal 53 ayat 2 UU No. 5 Tahun 1986 ditemukan dalam penjelasannya isyarat mengenai AAUPL tersebut, utamanya sehubungan dengan penggunaan kewenangan bebas (virj bestuur)

Dalam penjelasannya disebutkan sebagai berikut:

"Dalam pemerintahan yang bebas Badan atau pejabat Tata Usaha Negara yang bersangkutan bertugas:

1) Mengumpulkan fakta yang relevan

2) Mempersiapkan, mengambil dan melaksanakan keputusan yang bersangkutan dengan memperhatikan asas-asas hukum yang tidak tertulis; dan

3) Dengan penuh kelonggaran menentukan sendiri isi, cara menyusun dan saat mengeluarkan peraturan itu"

Ketentuan yang menyebutkan dalam mempersiapkan, mengambil dan melaksanakan keputusan yang bersangkutan dengan memperhatikan "asas-asas hukum yang tidak tertulis", haruslah diartikan bahwa asas-asas hukum tidak tertulis dalam penyelenggaraan pemerintahan maksudnya adalah AAUPL. Dengan demikian, secara implisit eksistensi AAUPL diakui dalam pasal 53 UU No. 5 Tahun 1986

Contoh dari hal ini adalah yurisprudensi MA tentang kasus yang dialami oleh Lindawati melawan Bupati Gianyar Bali yang pada tingkat pertama dan banding ia kalah, tapi menang dalam tingkat kasasi karena menurut MA tindakan Bupati Gianyar yang hanya membongkar warung milik Lindawati saja bertentangan 
dengan AAUPB yakni asas persamaan ${ }^{12}$. Karena di sekitar tempat tersebut banyak berdiri bangunan tanpa IMB tapi hanya rumah makan milik Lindawati saja yang dibongkar oleh Pemda. Jika melihat penjelasan dari UU No. 9 Tahun 2004, Asas-Asas Umum Pemerintahan Yang Baik yang dimaksudkan adalah yang tertera di UU No. 28 Tahun 1999 tentang penyelenggaraan negara yang bersih dan bebas dari korupsi, kolusi dan nepotisme, dimana asas-asas tersebut berupa: kepastian hukum, tertib penyelenggaraan Negara, keterbukaan, proporsionalitas, profesionalitas dan akuntabilitas. Ketidakcocokan antara asas-asas dalam UU No. 28 Tahun 1999 dengan Asas-Asas Umum Pemerintahan Yang Baik dalam bidang administrasi Negara adalah pada lingkup obyeknya, asas-asas dalam UU No. 28 Tahun 1999 mencakup seluruh penyelenggara Negara, sedangkan Asas-Asas Umum Pemerintahan Yang Baik hanya diberlakukan untuk eksekutif saja. Nafas antara kedua undang-undang tersebut berbeda, UU No. 5 Tahun 1986 paradigmanya adalah melindungi rakyat dari kesewenangwenangan penguasa sedangkan UU No. 28 Tahun 1999 paradigmanya adalah melindungi Negara dari KKN.

Menurut Ridwan HR, asas-asas yang terdapat dalam UU No. 28 Tahun 1999 itu adalah asas dari good governance yang menghendaki agar pemerintah bersifat lebih responsif supaya

\footnotetext{
12 Hal ini terdapat dalam Putusan Pengadilan Tata Usaha Negara (PTUN) Ujung Pandang Nomor 03/Srt.G/TUN/I 99I/P.TUN/Uj.Pdg/Acara Cepat, Putusan Pengadilan Tinggi Tata Usaha Negara (PTTUN) Ujung Pandang No.0I/BDG-G.TUN/PTTUN.U.Pdg, Putusan MA RI No.l0 K/TUN/I 992 tentang Sengketa Perizinan. Penggugat Nyonya Lindawati pemilik bangunan restoran Bali Sky Light yang terletak di Kabupaten Daerah Tingkat II Gianyar Bali, tergugat Bupati Kepala Daerah Tingkat II Gianyar, Keputusan Tata Usaha Negara(KTUN) yang digugat adalah Surat Perintah Bongkar dari Bupati Kepala Daerah Tingkat II Gianyar (SK Tanggal 5 Maret I99I Nomor 640/I96/PU//991). Pangkalan sengketa dalam putusan ini adalah SK Bupati Kepala Daerah Tingkat II Gianyar Nomor 640//92/PU/I99| tertanggal 5 Maret I99| dan SK Nomor 46 Tahun I99| tertanggal 16 Maret 199I tentang Perintah Bongkar Paksa. Secara teoritis kedua SK tersebut termasuk kategori keputusan yang bersumber dari wewenang bebas penguasa (vrij bestuur) yang didasarkan asas Freies Ermessen, terbukti SK tersebut telah memerintahkan bongkar paksa atas bangunan milik penggugat dengan alasan untuk pembangunan (proyek jalur hijau). Keputusan semacam ini dapat diuji dengan AAUPB oleh hakim. Berdasarkan penilaian Hakim, SK tergugat dikualifisir bertentangan dengan AAUPB yaitu asas persamaan, karena tidak memperlakukan sama dalam hal atau kasus yang sama.
} 
perkembangan bisnis menjadi lebih lancar. Makna good governance dalam Wikipedia adalah:

"Indeterminate term used in international development literature to describe how public institutions conduct public affairs and manage public resources. Governance is "the process of decision-making and the process by which decisions are implemented (or not implemented)". The term governance can apply to corporate, international, national, local governance or to the interactions between other sectors of society ${ }^{16}$ (istilah yang tidak tertentu, yang digunakan dalam pembangunan internasional untuk menggambarkan bagaimana institusi publik melakukan urusanya dan mengelola sumber daya publik. Governance adalah proses pengambilan keputusan dan proses mengimplementasikan atau tidak mengimplementasikan keputusan tersebut. Istilah governance dapat digunakan untuk korporasi, internasional, nasional, pemerintahan lokal atau interaksi antar sektor di masyarakat)."

Istilah good governance ini diperjelas oleh IMF dalam pernyataannya pada tahun 1996 ,

"promoting good governance in all its aspects, including by ensuring the rule of law, improving the efficiency and accountability of the public sector, and tackling corruption, as essential elements of a framework within which economies can prosper ${ }^{17}$." (memajukan tata pemerintahan yang baik pada semua aspek, termasuk memastikan aturan hukum, meningkatkan efisiensi dan akuntabilitas sektor publik dan pemberantasan korupsi adalah elemen penting dari kerangka kerja yang membuat ekonomi bisa makmur)."

Bahkan agar sebuah Negara mendapatkan pinjaman dana dari IMF, Negara tersebut harus memenuhi beberapa persyaratan yang diminta oleh IMF.

Berbeda dengan Good Governance yang menginstruksikan agar pemerintah lebih responsif dan tidak terlalu kaku agar perekonomian sebuah Negara bisa berjalan dengan optimal, good government menginginkan agar pemerintah memperhatikan

\footnotetext{
16 http://en.wikipedia.org/wiki/Good_governance, akses tanggal 4 juli 2013

17 Ibid.
} 
kehidupan dan kebahagiaan rakyatnya, menurut Thomas Jefferson kedua hal tersebut adalah satu-satunya objek yang sah dalam mewujudkan tata kelola pemerintahan yang baik/good government ${ }^{18}$. Good government inilah yang merupakan asas-asas umum pemerintahan yang baik.

Menurut Bagir Manan, meskipun yang tercantum dalam penjelasan pasal 53 hanya 7 asas saja tapi hal ini tidak menyebabkan asas-asas yang lain yang terdapat dalam kajian teoritik tidak dapat digunakan sebagai dasar gugatan, karena menurutnya Indonesia menganut juga hukum adat yang mana sama dengan AAUPB sebagai hukum tidak tertulis.

Tentang diperbolehkannya Asas-Asas Umum Pemerintahan Yang Baik menjadi landasan gugatan terhadap keputusan pejabat Tata Usaha Negara, H.D. van Wijk telah merumuskan hal-hal yang dapat dijadikan dasar pengujian terhadap tindakan organ pemerintah, yaitu ${ }^{20}$ :

a. Strijd met een algemeen verbindend voorschrift (Bertentangan dengan peraturan yang mengikat umum atau peraturan perundang-undangan)

b. Detournement de pouvoir (penyalahgunaan wewenang)

c. Het administratieve organ heft bij afweging van de betrokken belangen niet in redelijkheid tot de beschikking kunnen komen (organ pemerintah dalam mempertimbangkan berbagai kepentingan terkait untuk mengambil keputusan tidak mendasarkan pada alasan yang rasional)

d. Strijd anderzins met enig in het algemeen rechtsbewustzijn levend beginsel van behoorlijk bestuur (bertentangan dengan apa yang dalam kesadaran hukum umum merupakan asas-asas yang hidup/berlaku tentang pemerintahan yang baik)

Pengujian terhadap tindakan pemerintah, khususnya diskresi, dengan menggunakan peraturan tertulis kurang memadai karena

\footnotetext{
${ }^{18} \mathrm{http}: / /$ en.wikipedia.org/wiki/Good government, akses tanggal 4 juli 2013.

20 Ridwan HR, "Diksresi dan Tanggung Jawab Pejabat Dalam Penyelenggaraan Pemerintahan di Indonesia" (Disertasi-Universitas Airlangga, Surabaya, 20 I3), I8I.
} 
penggunaan diskresi itu sendiri yang berkenaan dengan wewenang yang tidak disebutkan secara tegas dalam peraturan perundangundangan. Maka pengujiannya dengan menggunakan asas-asas umum pemerintahan yang baik terutama asas larangan melampaui wewenang dan larangan penyalahgunaan wewenang ${ }^{21}$.

\section{AUPB Dalam UU No. 30 Tahun 2014}

Asas-asas umum pemerintahan yang baik (AAUPB) mendapatkan tempat terbaiknya di UU No. 30 Tahun 2014 tentang Administrasi Pemerintahan, istilah Asas-Asas Umum Pemerintahan yang Baik (AAUPB) diubah menjadi Asas Umum Pemerintahan yang Baik (AUPB) pada pasal 1 AUPB diartikan sebagai prinsip yang digunakan sebagai acuan penggunaan Wewenang bagi Pejabat Pemerintahan dalam mengeluarkan Keputusan dan/atau Tindakan dalam penyelenggaraan pemerintahan. Jika pada UU No. 9 Tahun 2004 AAUPB hanya dijadikan landasan gugatan di PTUN-itupun uraian asas-asanya hanya ada di penjelasan-dalam UU No. 30 Tahun 2014 menjadi ruh dari undang-undang tersebut. Posisi penting dari AUPB sudah mulai terlihat dari konsideran yang menyebutkan:

"bahwa dalam rangka meningkatkan kualitas penyelenggaraan pemerintahan, badan dan/atau pejabat pemerintahan dalam menggunakan wewenang harus mengacu pada asas asas umum pemerintahan yang baik dan berdasarkan ketentuan peraturan perundang-undangan."

Selanjutnya dalam Pasal 3 dengan tegas dinyatakan bahwa tujuan dari adanya UU No. 30 Tahun 2014 salah satunya adalah untuk menerapkan AUPB. Tindakan pemerintah wajib berdasarkan peraturan perundang-undangan dan AUPB, bahkan jika peraturan perundang-undangan tersebut tidak ada seorang pejabat pemerintah bisa menggunakan AUPB sebagai dasar acuan. Pasal 10 merinci jenis-jenis AUPB yang terdiri dari kepastian hukum; kemanfaatan; ketidakberpihakan; kecermatan; tidak 
menyalahgunakan kewenangan; keterbukaan; kepentingan umum; dan pelayanan yang baik. Pasal tersebut bukanlah pasal yang bersifat tertutup, artinya bukan hanya asas-asas yang tersebut saja yang bisa digunakan dalam penyelenggaraan pemerintahan. Asasasas selain itu bisa digunakan sebagai dasar dalam penyelenggaraan pemerintahan selama digunakan oleh hakim dalam pertimbangan putusan yang sudah mempunyai kekuatan hukum mengikat ${ }^{22}$.

Selanjutnya AUPB digunakan dalam penggunaan diskresi oleh pejabat pemerintahan, juga ketika menilai apakah sebuah diskresi termasuk mencampuradukkan wewenang atau tidak ${ }^{23}$. Seorang pejabat pemerintahan ketika memberikan izin, dispensasi, dan konsesi selain berdasarkan peraturan perundang-undangan juga harus memperhatikan AUPB. Juga ketika pejabat pemerintahan membuat, mencabut, dan membatalkan sebuah keputusan harus dengan memperhatikan AUPB.

Dari sekian banyak keistimewaan AUPB dalam UU No. 30 Tahun 2014 tentu menjadi perkembangan yang sangat positif bagi pembangunan hukum di Indonesia, ketika peraturan perundangundangan tidak bisa menjangkau setiap lini bidang pemerintahan yang perkembangannya sangat dinamis maka AUPB bisa menjadi barometer penyelenggaraan pemerintahan yang baik.

\section{Analisis Putusan PTUN yang bertentangan dengan AAUPB}

Dalam tulisan ini saya membahas dua contoh putusan sengketa TUN yang dianggap bertentangan dengan AAUPB.

1. Putusan kasasi MA No 385 KTUN yang membenarkan putusan banding No 33/B/2009/PT.TUN.MDN dari putusan pengadilan tingkat pertama No.63/G/2008/PTUN-MDN.

Perkara yang disengketakan adalah surat keputusan kepala kepolisian daerah Sumatera utara No. Pol: Skep/694/XI/2006 tentang pemberhentian tidak dengan hormat terhadap bripda Helga Musa Sitepu. Termohon kasasi yang dahulunya adalah

\footnotetext{
22 Pasal 10 UU No. 30 Tahun 2014 tentang Administrasi Pemeritahan.

23 Pasal 24 dan 3 I UU No. 30 Tahun 2014 tentang Administrasi Pemeritahan.
} 
penggugat berpendapat kalau tergugat telah mengeluarkan surat keputusan secara sewenang-wenang dan bertentangan dengan aturan dalam 13 PP No. 2 tahun 2003 tentang peraturan disiplin anggota kepolisian NKRI dan pasal 12 ayat 1 huruf a PP No. 1 tahun 2003 tentang pemberhentian anggota kepolisian NKRI, asas dalam AAUPB yang dilanggar adalah asas kepastian hukum dan asas kecermatan. Bunyi dari pasal 13 menyatakan "anggota kepolisian Negara Republik Indonesia yang dijatuhi hukuman disiplin lebih dari 3 kali dan dianggap tidak patut lagi dipertahankan statusnya sebagai anggota kepolisian Negara Republik Indonesia" sedangkan dalam pasal 12 ayat 1 huruf a tertera "apabila dipidana penjara berdasarkan putusan pengadilan yang telah berkekuatan hukum tetap dan menurut pertimbangan pejabat yang berwenang tidak dapat lagi dipertahankan untuk tetap berada dalam dinas kepolisian kepolisian negara republik Indonesia". Dari bunyi PP tersebut kemudian POLDA Sumatera Utara telah mengeluarkan pendapat hukum yang menyatakan "oleh karena itu anggota Polri yang telah melakukan tindak pidana dan telah mempunyai kekuatan hukum tetap tidak perlu diajukan ke sidang KKEP Polri apabila pejabat berwenang memberikan pertimbangan berupa rekomendasi bahwa yang bersangkutan masih layak dipertahankan untuk tetap berada dalam dinas Polri". Hal ini sesuai dengan pasal 11 ayat 1 peraturan Kapolri No. 8 Tahun 2006.

Penggugat/termohon kasasi sebelumnya dijatuhi hukuman 4 bulan 15 hari. Karena adanya keputusan yang sudah incraht dari PN Binjai, POLDA SUMUT/tergugat kemudian membentuk komisi kode etik Polri yang menyatakan penggugat tidak layak lagi menjadi anggota Kepolisian sehingga keluarlah surat keputusan Kepala Kepolisian Daerah Sumatera Utara No.Pol.Skep/694/XI/2006 tentang pemberhentian tidak hormat Bripda Helga Musa Sitepu. Ada dua poin utama yang oleh 
penggugat dijadikan landasan tidak sahnya surat keputusan tersebut, yakni:

a. Berdasarkan pasal 2 ayat 2 huruf d peraturan Kapolri No. 8 Tahun 2006, seharusnya yang membentuk komisi kode etik bukan Kapolda Sumatera Utara tetapi Kapolres Langkat. Hal ini juga penulis temukan dalam pasal 8 ayat 5 huruf $\mathrm{d}$ peraturan Kapolri No. 8 Tahun 2006. Dalam pasal tersebut yang seharusnya menjadi ketua komisi etik adalah Wakapoltabes/Wakapolres Metro atau kota karena yang bersangkutan jabatannya adalah Bripda.

b. Berdasarkan surat keputusan dari Kapolda Sumatera Utara No.Pol.Skpe/694/XI/2006, pemberhentian anggota Polri dapat dilakukan jika terlebih dahulu ada permintaan resmi oleh atasan terperiksa kepada Propam. Hal yang serupa juga penulis temukan dalam pasal 11 ayat 1 peraturan Kapolri No. 8 Tahun 2006 yang menyatakan "Penanganan pelanggaran Pasal 12, Pasal 13 dan Pasal 14 Peraturan Pemerintah Nomor 1 Tahun 2003 tentang Pemberhentian Anggota Polri serta Pasal 13 Peraturan Pemerintah Nomor 2 Tahun 2003 tentang Peraturan Disiplin Anggota Polri dilaksanakan apabila ada permintaan resmi oleh atasan Terperiksa kepada fungsi Propam". Kapolres Langkat selaku atasan yang berhak menghukum penggugat/pejabat yang berwenang telah mengeluarkan rekomendasi penilaian pada tanggal 22 Maret 2006 yang menyatakan penggugat masih layak untuk dipertahankan mengemban tugas profesi Polri dan masih layak dipertahankan menjadi anggota kepolisian NKRI.

Pada pertimbangannya, Mahkamah Agung mengatakan kalau tindakan tergugat dalam mengeluarkan surat keputusan pemberhentian tidak hormat terhadap bripda Helga Musa Sitepu bertentangan dengan peraturan perundang-undangan dan melanggar Asas-Asas Umum Pemerintahan Yang Baik yakni asas kecermatan. Yang juga menjadi perhatian oleh majelis MA adalah pernyataan dari pejabat yang berwenang-yakni 
kapolres Langkat-bahwa yang bersangkutan masih layak menjadi anggota polri. Pembentukan komisi etik juga tidak sesuai dengan peraturan perundang-undangan yang berlaku. Oleh karena putusan judex facti tidak ada yang bertentangan dengan peraturan perundang-undangan yang berlaku, maka MA menolak permohonan kasasi yang diajukan oleh kepala kepolisian daerah Sumatera Utara.

Asas-asas umum pemerintahan yang baik yang dilanggar dalam kasus ini adalah asas kecermatan. Asas kecermatan menghendaki agar pemerintah bertindak cermat dalam melakukan berbagai aktivitas penyelenggaraan tugas-tugas pemerintahan, sehingga tidak menimbulkan kerugian bagi warga Negara. Pemerintah harus mempertimbangkan secara cermat dan teliti semua faktor dan keadaan yang berkaitan dengan materi keputusan, mendengar dan mempertimbangkan alasan-alasan yang diajukan oleh pihak-pihak yang berkepentingan dan juga harus mempertimbangkan akibatakibat hukum yang muncul dari keputusan tata usaha tersebut ${ }^{24}$. Asas kecermatan yang dilanggar dalam beschikking di atas adalah tindakan komisi etik yang memberhentikan dengan tidak hormat tanpa adanya pernyataan tidak layak lagi menjadi anggota Polri bagi bripda Helga Musa Sitepu dari kapolres Langkat selaku pejabat yang berwenang. Selain itu juga dibentuknya komisi etik di lingkungan Polda Sumatera Utara yang seharusnya di lingkungan Polres Langkat.

2. Putusan kasasi No 489 K/TUN/2001 yang diajukan oleh Suhaili Saun melawan Ketua Badan Koordinasi Penanaman Modal (BKPM), putusan ini telah menjadi Yurisprudensi MA yang membenarkan putusan PTUN Jakarta dan membatalkan putusan PTTUN Jakarta. Yang menjadi objek gugatan adalah keputusan fiktif negatif dari Badan Koordinasi Penanaman 
Modal yang tidak mau mencabut surat izin bagi PT Volex Indonesia.

Permasalahan dalam perkara tersebut bermula dari PT Volex Indonesia yang tiba-tiba menempati tanah dan menggunakan fasilitas yang dimiliki PT Volex Batam Indah. Penggugat telah beberapa kali menyampaikan surat kepada tergugat terhadap tindakan yang dilakukan oleh PT Volex Indonesia, atas surat yang dilayangkan oleh pihak penggugat kemudian Badan Koordinasi Penanaman Modal selaku pengawas penanaman modal asing juga telah memberikan beberapa kali teguran kepada PT Volex Indonesia. Badan Koordinasi Penanaman Modal telah memberikan surat peringatan sampai tiga kali namun tidak ada respon dari pihak PT Volex Indonesia, karena tidak ada perkembangan lebih lanjut akhirnya penggugat mengirimkan surat lagi kepada Badan Koordinasi Penanaman Modal terkait tindak lanjut surat peringatan yang terakhir.

Setelah mendapatkan surat tanggapan terkait tindak lanjut yang akan dilakukan Badan Koordinasi Penanaman Modal terhadap PT. Volex Indonesia, ternyata Badan Koordinasi Penanaman Modal belum juga mencabut izin pendirian perusahaan tersebut. Karena tidak ada tindakan lebih lanjut oleh Badan Koordinasi Penanaman Modal dan merasa dirugikan oleh perilaku PT Volex Indonesia, akhirnya penggugat mendaftarkan perkara tersebut ke PTUN Jakarta dengan obyek sengketa keputusan fiktif negatif dari Badan Koordinasi Penanaman Modal. Penggugat mengajukan tiga alasan; tergugat melanggar undang-undang, tergugat mempergunakan wewenang untuk tujuan lain dan yang ketiga adalah pertimbangan yang salah dalam mengambil keputusan. Pada pengadilan tingkat pertama penggugat menang tapi di tingkat banding ia kalah dan akhirnya ia menang dalam kasasi.

Dalam tingkat kasasi, Mahkamah Agung menyalahkan PTTUN Jakarta yang menyatakan kasus ini sebagai ranah 
perdata karena berhubungan dengan pemilikan. Dalam pertimbangannya, Mahkamah Agung mengatakan kalau obyek sengketa adalah keputusan fiktif negatif yang berupa sikap diam dari tergugat terhadap surat permohonan penggugat tentang permohonan agar tergugat mencabut izin PT Volex Indonesia. Keterangan tentang keputusan fiktif negatif terdapat dalam pasal 3 UU No. 5 Tahun 1986 jika pejabat TUN tidak mengeluarkan keputusan yang dimohon sedangkan jangka waktunya sudah lewat, maka pejabat TUN tersebut dianggap menolak keputusan yang dimaksud.

Mahkamah Agung menyebutkan juga kalau tindakan pejabat TUN dalam hal ini Ketua Badan Koordinasi Penanaman Modal bertentangan dengan AAUPB, tapi MA tidak menyebutkan asas apa yang dilanggar. Mahkamah Agung hanya menyatakan seharusnya untuk mengeluarkan izin PT Volex Indonesia, Badan Koordinasi Penanaman Modal harus terlebih dahulu mencabut izin PT Batam Indah, menurut MA hal ini merupakan overlapping (tumpang tindih) karena disatu sisi izin untuk PT Volex Batam Indah masih berlaku sedangkan disisi yang lain tergugat juga mengeluarkan izin untuk PT Volex Indonesia. Melihat pernyataan penggugat yang menyatakan keputusan Badan Koordinasi Penanaman Modal tersebut bertentangan dengan asas kepastian hukum, mungkin yang dimaksudkan oleh MA adalah asas tersebut. Asas kepastian hukum menghalangi badan pemerintah menarik kembali suatu keputusan atau mengubahnya untuk kerugian yang berkepentingan. Asas ini menghendaki dihormatinya hal yang telah diperoleh seseorang berdasarkan suatu keputusan meskipun keputusan itu salah, asas ini berkaitan dengan prinsip praduga rechtmatig yang berarti setiap keputusan yang dikeluarkan oleh pejabat TUN dianggap benar selama belum dibuktikan sebaliknya atau dinyatakan sebagai keputusan yang bertentangan dengan hukum oleh hakim administrasi. Asas ini memberi hak kepada yang berkepentingan untuk mengetahui 
dengan tepat apa yang dikehendaki daripadanya, dengan asas ini surat keputusan tidak multi tafsir dan dapat diketahui tujuannya secara jelas ${ }^{25}$.

\section{Penutup}

Asas-Asas Umum Pemerintahan yang Baik sebagai asas hukum yang tadinya tidak tertulis dan diakui di Indonesia, AsasAsas Umum Pemerintahan yang Baik dinyatakan secara eksplisit dalam peraturan perundang-undangan semenjak keluarnya UU No. 9 Tahun 2004, penjelasan pasal 53 membatasi AAUPB hanya dalam 6 jenis macam saja yang mana keenam asas tersebut adalah asas yang terdapat dalam UU No. 28 Tahun 1999. Legalitas AAUPB mendapatkan eksistensinya dalam UU No. 30 Tahun 2014, bahkan menempati posisi yang sangat strategis, AAUPB menjadi ruh dan barometer bagi penyelenggaraan pemerintahan.

Contoh dari putusan Mahkamah Agung dan digunakan sebagai yurisprudensi yang penulis sebutkan membuktikan bahwa selain berdasarkan peraturan perundang-undangan, gugatan juga bisa karena pelanggaran AAUPB oleh pejabat Tata Usaha Negara. Dalam berbagai kasus, dasar gugatan karena AAUPB tidak berdiri sendiri tapi juga disandingkan dengan pelanggaran peraturan perundang-undangan. Namun ada putusan yang murni karena pelanggaran AAUPB yakni dalam kasus Lindawati dengan Bupati Gianyar Bali yang kalah dalam tingkat pertama dan kedua namun menang dalam kasasinya, menurut MA perbuatan Pejabat TUN yang demikian bertentangan dengan asas persamaan. Gabungan antara pelanggaran AAUPB dengan peraturan perundangundangan terdapat dalam putusan kasasi MA yang telah menjadi yurisprudensi antara Suhaili Saun (pemegang saham di PT Volex Batam Indah) dengan Ketua Badan Koordinasi Penanaman Modal, meskipun penggugat mendalilkan juga bahwa selain melanggar AAUPB yaitu asas kepastian hukum, tergugat juga melanggar pasal

25 Muin Fahmal, Peran Asas-Asas Umum Pemerintahan Yang Baik Dalam Mewujdukan Pemerintahan Yang Bersih, (Yogyakarta: UII Press, 2006), I 57 
2 huruf b UU No. 1 Tahun 1967 tentang Penanaman Modal Asing. Sedangkan dalam kasus pemberhentian Bripda Helga Musa Sitepu oleh Kepala Kepolisian Daerah Sumatera Utara, surat keputusan tersebut melanggar pasal 2 ayat 2 huruf d dan pasal 11 ayat 1 peraturan KAPOLRI No 8 Tahun 2006 dan bertentangan dengan asas kecermatan.

\section{Daftar Pustaka}

HR, Ridwan, Disksresi dan Tanggung Jawab Pejabat Dalam Penyelenggaraan Pemerintahan di Indonesia, disertasi, Universitas Airlangga Surabaya, 2013 - Hukum Administrasi Negara, Edisi Revisi, Cetakan Kedelapan, Jakarta: Raja Grafindo Persada, 2013

http://en.wikipedia.org/wiki/Good_governance, akses tanggal 4 juli 2013

Marbun, SF., Eksistensi Asas-Asas Umum Penyelenggaraan Pemerintahan Yang Layak Dalam Menjelmakan Pemerintahan Yang Baik dan Bersih Di Indonesia, Disertasi, tidak diterbitkan, program pasca sarjana fakultas hukum Universitas Padjajaran Bandung, 2001 Peradilan Administrasi Negara dan Upaya Administratif di Indonesia, Yogyakarta: UII Press, 2011

Muin Fahmal, Peran Asas-Asas Umum Pemerintahan Yang Baik Dalam Mewujudkan Pemerintahan Yang Bersih, Yogyakarta: UII Press, 2006

UU No. 5 Tahun 1986 tentang Peradilan Tata Usaha Negara

UU No 9 Tahun 2004 tentang perubahan atas UU No. 5 Tahun 1986 tentang Peradilan Tata Usaha Negara.

UU No. 51 Tahun 2009 tentang perubahan kedua atas UU No. 5 Tahun 1986 tentang Peradilan Tata Usaha Negara

UU No. 14 Tahun 1970 tentang ketentuan-ketentuan pokok kekuasaan kehakiman

UU No. 30 Tahun 2014 tentang Administrasi Pemerintahan

UUD 1945 